Eduvest - Journal of Universal Studies

Volume 1 Number 11, November 2021

p- ISSN 2775-3735 e-ISSN 2775-3727

\title{
DEVELOPMENT OF PRODUCTION-BASED LEARNING MODELS FOR OPTIMIZING THE TECHNOPRENEURSHIP SPIRIT IN HIGHER EDUCATION
}

Idi Jang Cik

Universitas Negeri Padang, Padang, Indonesia

E-mail: Idijangcik@sttpagaralam.ac.id

\begin{tabular}{ll}
\hline ARTICLE INFO & ABSTRACT \\
\hline Received: & Development of production-based learning models carried
\end{tabular}

October, $26^{\text {th }}$ out to seek validity, practicality and effectiveness in the

2021

Revised:

November, $16^{\text {th }}$

2021

Approved:

November, $18^{\text {th }}$

2021 application of technopreneur courses in universities. Production-based learning model is an alternative to develop students' skills, attitudes and knowledge that are relevant today. Research and development is used to test the validity of experts through Focus Group Discussions (FGD), then limited trials are carried out in the development of this production-based learning model. From the processes carried out, a new syntax development is produced which refers to the previous model syntax. The development of the syntax sequence is (1) an analysis of the curriculum and characteristics of students; (2) Product identification and analysis; (3) Make important questions about the product; (4) Question mapping; (5) analysis of equipment and materials needed for the product to be made; (6) create a business plan (7) product manufacturing process; (8) small-scale operations that include promotion and sales, (9). Summative evaluation; From the stages of the research carried out, the resulting Aiken's $V$ value is 0.812 with a valid category, while the calculation of the Effectiveness value gets the results of 82.22 (effective) and Practicality of 89.33 (very practical). So it can be said that the production-based learning development model has Idi Jang Cik. (2021). Development of Production-Based Learning Models for Optimizing the Technopreneurship Spirit in Higher Education. Journal Eduvest. 1(11): 1305-1312

How to cite:

E-ISSN:

Published by: https://greenpublisher.id/ 


\begin{tabular}{ll}
\hline & $\begin{array}{l}\text { validity, practicality and effectiveness values that meet } \\
\text { the requirements, so it is feasible to apply. }\end{array}$ \\
\hline KEYWORDS & $\begin{array}{l}\text { Production-Based Learning Model, Learning Model, } \\
\text { Production-Based }\end{array}$ \\
\hline CC) (i) (O) & $\begin{array}{l}\text { This work is licensed under a Creative Commons } \\
\text { Attribution-ShareAlike 4.0 International }\end{array}$ \\
\hline
\end{tabular}

\section{INTRODUCTION}

Indonesia through formal education seeks to build the implementation of education at various levels from basic to higher education so that it can realize the achievement of educational goals based on the reference to the national education system contained in the National Education System Law Number 20 of 203 which says: "Education has the function of developing abilities and form a dignified national character and civilization in the context of educating the nation's life, and aims to develop the potential of students to become human beings who believe and fear God Almighty, have noble character, are healthy, knowledgeable, capable, creative, independent, and become citizens democratic one".

Adapting to the demands of the era of globalization, various nations have developed a knowledge-based economy, which prioritizes increasing quality human resources with global capabilities to support the economy. In sustaining economic growth, it must be based on knowledge-based education to find out and develop information and knowledge as a key basis for success (Kefela, 2010).

Mastery of science and technology as one of the skills that is able to provide the ability to be able to compete globally through the free market economy (MEA) in the perspective of economic, social and political culture that individual human capacity must continue to be improved in order to survive and compete in increasingly difficult conditions of economic growth. Education is an opportunity to be able to change all the limitations of skills and knowledge possessed by individuals.

Education is the main effort in providing the community with knowledge as a social foundation that is able to serve as a support for democratic-based knowledge, development of capabilities in the formation of a civilized nation, dignity and character in the intellectual life of the nation through education.

Components in learning have been determined so that the learning process can run successfully and effectively, the learning approach plays a role in achieving the goals of students with character so that university graduates have competitive qualities.

Learning is often boring for students, including in entrepreneurship courses which in the learning process lecturers also experience difficulties in providing understanding to students in growing characteristics in being competitive to become entrepreneurs. Many college graduates who have completed their education are one of the contributors to the highest unemployment rate in Indonesia according to (Hadi, Wekke, \& Cahaya, 2015).

Around $12.5 \%$ in 2020 of the total unemployed in Indonesia are graduates from tertiary institutions with a diploma to a bachelor's degree (Akita \& Miyata, 2021).

The increase in unemployment is caused by several factors, especially the lack of skills and knowledge in seeing opportunities to survive and compete in competing with developments in the industrial revolution era and interest in entrepreneurship. Therefore, entrepreneurship courses are one of the characteristics of students who have competencies 
that are ready to compete in the free market to improve the nation's economy in general and reduce unemployment in Indonesia (Apriana, Kristiawan, \& Wardiah, 2019).

The readiness of students in developing entrepreneurial skills must be real and clear in the implementation in the field so that the skills growth process can continue to develop, one of which is the practicum learning process that teaches students to directly enter the field in running a business that is relevant to the interests and talents of students and assisted with the lecturer as a facilitator (Kusumaningrum \& Djukri, 2016).

The integration of learning into the entrepreneurial model has been carried out to provide knowledge to students on the concept of entrepreneurship so that the learning process is achieved in accordance with the objectives of the course (Yulastri \& Hidayat, 2017). The production-based approach is an alternative to the concept of entrepreneurship so that graduates can have quality in creating jobs. Quality is a value that must be owned by state resources in order to be able to grow to be better, productive and independent in creating success in building gaps in the economy that exists in a country (Porter \& Kramer, 2019).

The role of education is very important, quality education will be able to give birth to the intellectual capital and technological capital needed in order to build a knowledge-based society. Thus, learning activities carried out through the Educational pathway must be designed to foster human knowledge in having economic-based skills.

According to Micu (2011), knowledge-based economy In the modern era of globalization, universities must follow the pattern of business behavior in their learning, this aims to make graduates smart in responding to opportunities and able to take advantage of the market, the strategic culture that must be done is to increase the alignment of students' entrepreneurial abilities with standard alignment. worldwide international.

To promote knowledge-based economic development, the government needs to facilitate economic change as a result of the modernization process, by helping students to be able to create new opportunities and generate income through technological means. an investment.

Responding to the pressure generated by technological changes at this time provides opportunities for universities to be able to have good strategies in making changes in achieving the goals of developing students' skills and knowledge by using educational management in accordance with developments in the current era of globalization.

The implementation of the highest education such as universities in Indonesia has a role that must be carried out, namely the tri dharma of higher education, HELTS 2003 2010 shows some expectations from universities in producing:

1) Graduates who are intellectual as citizens with responsible and competitive capabilities.

2) Community development must be able to contribute to the state.

3) An incubator is a system development that functions to assist in integrating technology into existing habits in building a knowledge-based economy.

Quality human resources is the dream of universities in producing good graduates in an effort to improve the economic development of the nation and state. Good economic growth will have an impact on the welfare of the people in the country through activities in entrepreneurship providing opportunities to improve the quality of the country's economy. Schumpeter 1911 said that there is a close relationship between economic growth and entrepreneurship in the country (Sugiharto, Johnson, De Aguiar, Alloatti, \& Roke, 2008). So that understanding in improving the economy both in the country must be dominated by people who have a 


\section{Idi Jang Cik}

productive entrepreneurial spirit in an effort to improve a better standard of living and use productive age to compete and increase mastery of facilities such as technology.

According to Henderson (2006), the existence of entrepreneurship plays an important influence in the economic progress of a country. Entrepreneurs, according to Aes (2006), develop new companies that can create new jobs and increase productivity through the use of technology.

Thus, the role of universities in improving the country's economic development is through fostering and creating entrepreneurial startups through the educational process. Universities need to increase the desire and passion of students in entrepreneurship so that the number of entrepreneurs can increase. Therefore, universities are required to develop their education system through increasing the role of universities as a driver of future economic growth through productive learning activities (Urbano \& Guerrero, 2013).

Related to the concept of creating entrepreneurship through education, it can be explained again the role of universities through HELTS 2003-2010 which states that specifically universities are required to produce graduates who have entrepreneurial abilities and have a high interest in becoming entrepreneurs.

Although the main function of universities is to deliver knowledge and technology issues through competencies in their respective disciplines. However, based on the experience of universities in all major European countries, according to Gunther and Wagner (2007), a number of European universities are undergoing transformation, with their traditional mission of education and research being replaced by the commercialization of innovative science and technology for economic growth (Klofsten et al., 2019).

Reflecting on neighboring countries such as Malaysia and Singapore, universities in these countries have the main function to provide quality higher education, develop education and research as well as develop entrepreneurship and increase the involvement of universities with industry.

Based on the things stated above, it is deemed important to carry out educational development and innovation that can increase the desire to carry out entrepreneurial activities. Develop entrepreneurial activity-based learning through a student center learning approach.

To prepare graduates who To be able to compete globally, universities must have a good strategy in creating graduates who have a creative spirit to be able to fill the global market in utilizing the fields of technological knowledge, art and entrepreneurship as the key to success in the development of the 21 st century.

Globalization has its own challenges in crushing the workforce as an increase in the strength of human resources in the 21st century, Sudlow (2018) said that competition in current conditions is more about the ability and mastery of technology that has been designed to optimize capabilities and skills in exploiting opportunities such as using technology as a source of search. fast and accurate information. Edmon (2014) principles in interacting between humans and computers have developed such as in IoT and EoP which must be considered by education providers in the 21 st century.

Product-based learning is still limited to product creation and has not focused on directions for promoting business and conducting transactions through online media (Hassan, Nadzim, \& Shiratuddin, 2015). Students feel complaints when looking for customers if it has to be done offline because the target farmers are narrow and limited to certain environments. This causes students to only try to take learning steps where the process has just arrived at producing a product while the resulting product basically has a selling value based on the abilities obtained. 
Based on observations and interviews with lecturers and students that have been carried out, one of the contributing factors is the practice of the Technopreneur course, and the learning model used is limited to steps to guide students to create an activity in learning to provide better output and distribute economic value. in creativity to produce a final product.

From the above problems, a change in learning is needed based on strengthening knowledge and skills in the use of technology, which can guide students and students in developing their creativity in learning so that they can improve skills and learning outcomes.

The problems that occur in the field, then become a consideration for researchers to develop product-based learning models that already exist and are applied to previous students. Development and innovation carried out to become solutions and optimization of desired learning outcomes. This is an effort to improve the quality of graduates and the competitiveness of graduates in responding to changes in the learning paradigm of the 21 st century. Universities, especially lecturers, need to prepare appropriate strategies to deliver students to be able to face the challenges and business opportunities of the 21st century.

Universities are required to be able to guarantee the quality of graduates who have the ability to compete with global standards and are not left behind in the international market by applying reliable skills in entrepreneurship in the 2I century. This development is an effort to anticipate educational problems that will develop as well as a way out of the problems of education in the era of globalization.

\section{RESEARCH METHOD}

This research is a research \& development design. According to Borg (1989), the implementation of Research and Development $(R \& D)$ is an effort to develop or produce and validate a production used in learning. According to Putra (2012), the Research and Development (R\&D) method is a deliberate, systematic research aimed at finding findings, formulating, perfecting, developing, producing, testing the effectiveness of superior products, models, methods/strategies/methods, services, special procedures, new, effective, efficient, productive and meaningful.

This study uses the ADDIE model. This model was adapted for the following reasons:

1. Simpler than other models.

2. Easy to learn.

3. The structure is systematic; first step to fifth step.

4. The procedure cannot be done randomly because of its characteristics.

\section{RESULT AND DISCUSSION}

The result of research and development is the creation of a production-based learning model in technopreneur courses with nine syntaxes, namely (1) curriculum analysis and student characteristics, (2) product identification and analysis, (3) important product questions, (4) question mapping, ( 5) analysis of the need for tools and materials from the product to be made, (6) making a business plan, (7) the product manufacturing process, and (8) business operations (promotion and marketing.) Evaluation of learning as shown in the following figure: 


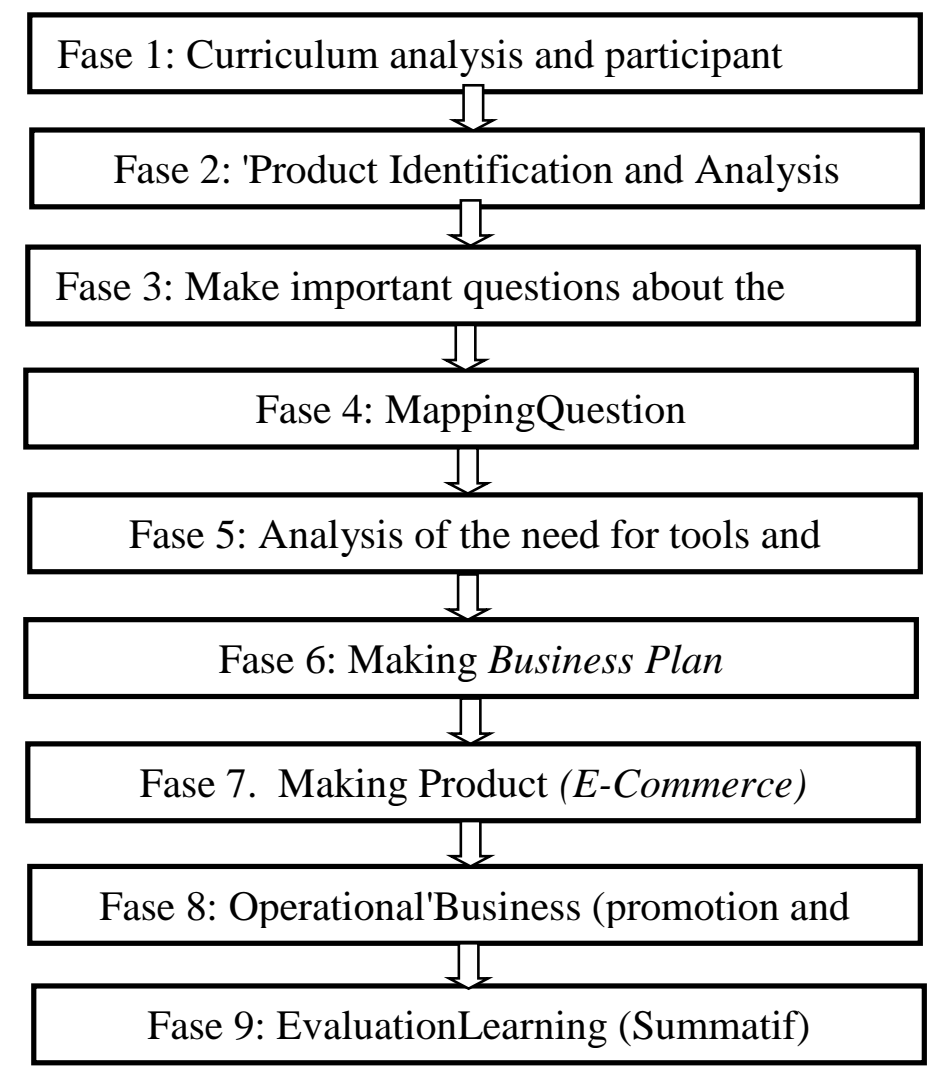

Figure 1 Syntax of Production Based Development Model Learning

The development of this production-based learning model also produces several products in the form of books, namely (1) Model Books, (2) Textbooks, (3) Lecturer Guidebooks, (4) Student Guidebooks. Each product is validated and assessed by several experts (expert judgment). The results of the validation are summarized in the following table:

Table 1. Summary of Product Validation

\begin{tabular}{llcl}
\hline No & Validation & Score Aikens'V & Category \\
\hline 1 & Model Book & 0.804 & Valid \\
\hline 2 & Application Guide & 0.816 & Valid \\
\hline 3 & Lecturer's Handbook & 0.814 & Valid \\
\hline 4 & Student Guide & 0.808 & Valid \\
\hline
\end{tabular}

The validation results show that all items made are valid, which indicates that they can be used for further study and development.

The results of the practicality test of the production based learning model were carried out by lecturers and students through lecturer and student response questionnaires. Response questionnaires were given to 3 lecturers to test the practicality of using the production based learning model. Student response questionnaires were given to 30 students to see the practicality of using the production-based learning model. 
The test results show that the lecturer's production-based learning model has a very practical category with an average percentage of 86.33 percent. These findings indicate that the production-based learning model that has been established makes it easier for lecturers to help students learn independently and at the same time assisting lecturers in understanding the meaning of learning materials. Students' answers with an average assessment percentage of 84.63 percent with a very practical category were used to assess the practicality of the production-based learning approach (Rocha et al., 2018). These findings indicate that the highly practical categories designed can help students learn information more easily (Martins, Costa, \& Onofre, 2015).

It is easier for students to understand learning when they use practical production-based learning strategies. A reliable, practical, and successful learning model can improve student learning outcomes, according to (PUYADA, Ridwan, \& Ganefri, 2013). A good learning model can make learning fun for students because they are more motivated to finish learning to see what things they can develop afterwards.

In this study, the efficacy of the model is determined by its capacity to engage students in learning and facilitate understanding of the learning material. Effective learning models can help students view learning models for better knowledge, in addition to increasing learning activities and outcomes. The learning model is evaluated in terms of student learning outcomes in this evaluation.

The effectiveness of the learning process is assessed by using a learning outcome test. Student learning outcomes are the skills they acquire after going through the learning process. The learning experience is in the form of effective learning activities that help students achieve their learning goals. The purpose of evaluating learning outcomes is to determine the level of success of the teaching and learning process that has been implemented (Spronken-Smith, Walker, Batchelor, O'Steen, \& Angelo, 2012).

From the description, it shows that the use of the production based learning model that was developed makes it easier for students to understand the material, so that student learning outcomes become better as stated by Harun Rasyid and Mansur (2009: 03) "evaluation is the process of determining the extent to which the learning process has been achieved" Based on the learning outcomes of the experimental class and control class for Technopreneur learning, it shows that there is a significant difference between the results of learning the experimental class and the control class where the experimental class is better than the control class. So, it can be concluded that learning using the production based learning model can be said to be effective. in improving student learning outcomes.

\section{CONCLUSION}

Production-based learning model is an alternative learning model that is suitable for technopreneur courses, by using this model, learning will be more meaningful. Moreover, the production-based learning model that has been applied so far can help students prepare to enter the world of work, be able to develop critical thinking, and have good morals. Therefore, it can provide support to students to be more active in the learning process which has an impact on the results of the learning process and its results.

\section{REFERENCES}

Akita, Takahiro, \& Miyata, Sachiko. (2021). Urban and Rural Dimensions of the Role of Education in Inequality: A Comparative Analysis between Indonesia, Myanmar, and the Philippines. In Rural-Urban Dichotomies and Spatial Development in Asia (pp. 127-166). Springer. 


\section{Idi Jang Cik}

Apriana, Dina, Kristiawan, Muhammad, \& Wardiah, Dessy. (2019). Headmaster's competency in preparing vocational school students for entrepreneurship. International Journal of Scientific \& Technology Research, 8(8), 1316-1330.

Hadi, Cholichul, Wekke, Ismail Suardi, \& Cahaya, Andi. (2015). Entrepreneurship and education: creating business awareness for students in East Java Indonesia. Procedia-Social and Behavioral Sciences, 177, 459-463.

Hassan, Shahizan, Nadzim, Siti Zaleha Ahmad, \& Shiratuddin, Norshuhada. (2015). Strategic use of social media for small business based on the AIDA model. Procedia-Social and Behavioral Sciences, 172, 262-269.

Kefela, Ghirmai T. (2010). Knowledge-based economy and society has become a vital commodity to countries. International NGO Journal, 5(7), 160-166.

Klofsten, Magnus, Fayolle, Alain, Guerrero, Maribel, Mian, Sarfraz, Urbano, David, \& Wright, Mike. (2019). The entrepreneurial university as driver for economic growth and social change-Key strategic challenges. Technological Forecasting and Social Change, 141, 149-158.

Kusumaningrum, Sih, \& Djukri, Djukri. (2016). Pengembangan perangkat pembelajaran model project based learning $(\mathrm{PjBL})$ untuk meningkatkan keterampilan proses sains dan kreativitas. Jurnal Inovasi Pendidikan IPA, 2(2), 241-251.

Martins, Maria, Costa, João, \& Onofre, Marcos. (2015). Practicum experiences as sources of pre-service teachers' self-efficacy. European Journal of Teacher Education, $38(2), 263-279$.

Porter, Michael E., \& Kramer, Mark R. (2019). Creating shared value. In Managing sustainable business (pp. 323-346). Springer.

PUYADA, DENO, Ridwan, Ridwan, \& Ganefri, Ganefri. (2013). Pengaruh Model Pembelajaran Kooperatif Tipe Student Teams Achievement Divisions Berbantu Modul Terhadap Pemahaman Konsep Menggunakan Hasil Pengukuran Kelas X Semester I SMK Negeri 1 Pariaman. Pendidikan Teknik Elektro, 1(1).

Rocha, Suiá, Sales, Aldo, Berndt, Alexandre, Alves, Fabiana, Sampaio, Fernanda, Overbeck, Gerhard, Albuquerque, Lidiamar, Nicodemo, Maria Luiza, Fernandes, Paulo, \& Santos, Sandra. (2018). Brazilian Critical Review to the "Guidelines for quantitative biodiversity assessments in the livestock sector."

Spronken-Smith, Rachel, Walker, Rebecca, Batchelor, Julie, O’Steen, Billy, \& Angelo, Tom. (2012). Evaluating student perceptions of learning processes and intended learning outcomes under inquiry approaches. Assessment \& Evaluation in Higher Education, 37(1), 57-72.

Sugiharto, A. B., Johnson, Claes Magnus, De Aguiar, H. B., Alloatti, L., \& Roke, S. (2008). Generation and application of high power femtosecond pulses in the vibrational fingerprint region. Applied Physics B, 91(2), 315-318.

Urbano, David, \& Guerrero, Maribel. (2013). Entrepreneurial universities: Socioeconomic impacts of academic entrepreneurship in a European region. Economic Development Quarterly, 27(1), 40-55.

Yulastri, Asmar, \& Hidayat, Hendra. (2017). Developing an Entrepreneurship Module by Using Product-Based Learning Approach in Vocational Education. International Journal of Environmental and Science Education, 12(5), 1097-1109. 